II presente documento viene fornito attraverso il servizio NILDE dalla Biblioteca fornitrice, nel rispetto della vigente normativa sul Diritto d'Autore (Legge n.633 del 22/4/1941 e successive modifiche e integrazioni) e delle clausole contrattuali in essere con il titolare dei diritti di proprietà intellettuale.

La Biblioteca fornitrice garantisce di aver effettuato copia del presente documento assolvendo direttamente ogni e qualsiasi onere correlato alla realizzazione di detta copia.

La Biblioteca richiedente garantisce che il documento richiesto è destinato ad un suo utente, che ne farà uso esclusivamente personale per scopi di studio o di ricerca, ed è tenuta ad informare adeguatamente i propri utenti circa i limiti di utilizzazione dei documenti forniti mediante il servizio NILDE.

La Biblioteca richiedente è tenuta al rispetto della vigente normativa sul Diritto d'Autore e in particolare, ma non solo, a consegnare al richiedente un'unica copia cartacea del presente documento, distruggendo ogni eventuale copia digitale ricevuta.

Biblioteca richiedente: Biblioteca Ingegneria e Medicina - Sede di Medicina 'Universita' di Brescia

Data richiesta: 30/01/2017 11:04:14

Biblioteca fornitrice: $\quad$ Biblioteca Federata di Medicina - Polo Dental School. - Università di Torino

Data evasione: 30/01/2017 11:11:50

Titolo rivista/libro: $\quad$ Acta odontologica Scandinavica (Online)

Titolo articolo/sezione: Dental trauma and bicycle safety: a report in Italian children and adolescents

Autore/i: Amadori F, Bardellini E, Copeta A, Conti G, Villa V, Majorana A

ISSN: $1502-3850$

DOI: $10.1080 / 00016357.2017 .1279345$

Anno: 2017

Volume: Jan 24

Fascicolo: $\operatorname{Jan} 24$

Editore:

Pag. iniziale: Epub ahead of $p$

Pag. finale: Epub ahead of $p$ 


\section{Acta Odontologica Scandinavica}

\section{Dental trauma and bicycle safety: a report in Italian children and adolescents}

\section{Francesca Amadori, Elena Bardellini, Alessandro Copeta, Giulio Conti, Valerio Villa \& Alessandra Majorana}

To cite this article: Francesca Amadori, Elena Bardellini, Alessandro Copeta, Giulio Conti, Valerio Villa \& Alessandra Majorana (2017): Dental trauma and bicycle safety: a report in Italian children and adolescents, Acta Odontologica Scandinavica, DOI: 10.1080/00016357.2017.1279345

To link to this article: http://dx.doi.org/10.1080/00016357.2017.1279345

曲 Published online: 24 Jan 2017.

Submit your article to this journal $[\pi$

Цlll Article views: 3

View related articles $₫$

View Crossmark data $\nearrow$ 


\title{
Dental trauma and bicycle safety: a report in Italian children and adolescents
}

\author{
Francesca Amadori ${ }^{\mathrm{a}}$, Elena Bardellini ${ }^{\mathrm{a}}$, Alessandro Copeta ${ }^{\mathrm{b}}$, Giulio Conti ${ }^{\mathrm{c}}$, Valerio Villa ${ }^{\mathrm{b}}$ and \\ Alessandra Majorana ${ }^{a}$ \\ ${ }^{a}$ Department of Medical and Surgical Specialities, Radiological Sciences and Public Health, Dental School, University of Brescia, Brescia, Italy; \\ ${ }^{b}$ Department of Mechanical and Industrial Engineering, University of Brescia, Brescia, Italy; 'Department of Oral Surgery, University Vita- \\ Salute S. Raffaele, Milan, Italy
}

\begin{abstract}
Objectives: This retrospective study aims to analyze the pattern of oro-facial trauma from bicycle accidents in Italian children and adolescents, focusing on the safety devices used.

Methods: The medical records of 1405 patients of the Dental Clinic of the University of Brescia, between the age of 0 to 18 , who experienced a dento-facial trauma from the use of a bicycle, were analyzed. Data regarding age, gender, weight, height, dominant hand, type of bicycle, use of safety devices, location and type of dental trauma, teeth involved, bone fractures and soft tissue lesions were recorded. Statistical analysis was performed.

Results: The majority of the traumatic events occurred in children within the 8-10 years of age-range; 1085 teeth were injured, of which 975 permanent teeth (89.9\%) and 110 primary teeth (10.1\%). The most common dental lesions were the coronal fractures (complicated and not complicated) while the most frequently involved teeth were the upper central incisors; $11 \%$ of patients were also treated for maxillo-facial fractures. A protective helmet was worn only in $3 \%$ of the cases; not one patient wore a mouth-guard. The use of helmets was more frequent in children and adolescents riding racing-bikes competitively, compared to those who were mountain bikers $(p<0.05)$.

Conclusions: Bicycle accidents can have serious oro-facial consequences. Therefore, national and regional efforts should be made in Italy to promote head and mouth protection in cycling.
\end{abstract}

\section{ARTICLE HISTORY}

Received 20 May 2016 Revised 24 November 2016 Accepted 2 January 2017

\section{KEYWORDS}

Injuries; prevention; child

\section{Introduction}

Cycling is a very common sport/activity; it is sometimes used as a means of transport, for sport or simply for fun. Unfortunately, motorcycle and bicycle accidents represent approximately $50 \%$ of all traffic accidents. Cyclists upon impact risk severe injuries [1,2], such as traumatic brain injury (TBI) or dental and facial lesions [3]. Other than the initial physical discomfort, dental injuries can also have functional, social, economic and psychological consequences $[4,5]$. Thomson et al. [6] stated that the use of a bicycle helmet reduces the risk of facial injuries by $65 \%$ but it does not significantly reduce the risk of dental traumas due to the lack of protection for the lower part of the face. Helmet use among cyclists is more widespread in the USA and Canada, than in Europe. In fact, helmets are worn by more than $50 \%$ of cyclists in the USA and Canada [6] compared to $12 \%$ of cyclists in Germany, $13-15 \%$ in Finland, $16-34 \%$ in UK, $17 \%$ in Sweden, $7 \%$ in Switzerland and $6 \%$ in Norway. In Denmark, $68 \%$ of children (aged $0-5$ ) who are passengers on bicycles wear helmets. Overall in Europe, helmets are used by $34 \%$ of children between 6 and 9 . Meanwhile, only $5 \%$ of cyclists aged $10-25$, and just $3 \%$ of those 25 and older wear helmets $[7,8]$. In Italy, the use of helmets is recommended but not mandatory and there is no data in literature concerning the use of bicycle helmets.
The prevalence of pediatric traumatic dental injuries ranges from 4 to $59 \%$, but these injuries represent approximately $20 \%$ of all the injuries at preschool age $[9,10]$. The aetiology of paediatric traumatic dental injuries includes accidental falls, sport-related trauma, vehicle crashes (car, motorbike and bicycle accidents), and violence [11,12]. A significant proportion of traumatic dental injuries in the USA is caused by falls off the bicycle or accidents. Out of 200000 bicycle accidents reported, approximately 1:2 involved children. Children in the 5-14 year age group have the highest incidence of bicycle-related injuries, even if younger children are also commonly injured [13]. Boys are at a greater risk than girls, with an accident ratio of boys to girls varying from 2:1 to $4: 1$ and they have more facial injuries than girls [14]. Considering the high rate of dental and facial trauma for bicycle accidents, particularly in children, the aim of this research was to review and analyze the aetiology, frequency and distribution of oro-facial trauma in Italy, identifying the pattern of bicycle trauma in children with special regards to the safety devices used.

\section{Methods}

This retrospective study was carried out on the medical records of patients (aged from 0 to 18 years) who visited the 
Dental Clinic of the University of Brescia for a dento-facial trauma due to the use of a bicycle during the period January 2010-December 2014.

For each patient's medical record, the following data were recorded: age $(Y)$, gender $(M / F)$, weight $(K g)$, height $(\mathrm{cm})$, dominant hand $(\mathrm{R} / \mathrm{L})$, type of bicycle (racing bikes included professional cycling on road or track, mountain bikes included all other types of bikes), type of activity (adventure biking, if used on a country/mountain road or if off-road, and non-adventure riding, if used on normal roads), use of safety devices (athletic mouthguards, helmets.), location and type of dental trauma (according to the Andreasen classification) [14], teeth involved, bone fractures and soft tissue lesions (swelling or lacerations). The patients with incomplete charts were excluded from the study. Data were entered in a Microsoft Excel 2012 database for Macintosh.

Due to the retrospective nature of this study, in order to comply with the ethic requirements, an exemption was granted in writing by the University of Brescia IRB. The study was conducted in compliance with the principles expressed in the Declaration of Helsinki.

\section{Statistical analysis}

The data were analyzed using SPSS version 19.0 (SPSS Inc., Chicago, IL), conducted following an intention-to-treat analysis using the last value forward method. The normal distribution of the sample was analyzed using the Kolmogorov-Smirnov test $(p<0.05)$, and the difference between the racing group and the mountain bike group was calculated through the Exact Fisher test. The statistical analysis was conducted at a $95 \%$ confidence level, and a $p<0.05$ was considered statistically significant.

\section{Results}

Over a five-year period, 1951 patients of all ages were treated at the Dental Clinic of the University of Brescia for a dento-facial traumatic event; of which, 1405 patients were aged $0-18$ years at the time of trauma. A total of 520 children $(37 \%)$ (mean age $10.7 \pm 3.36$ years, range $5-18$ years) experienced a bicycle accident or fall and therefore were included in the study. The ratio between males and females was almost 3:1, when 385 (74\%) of the patients were male (mean age $10.9 \pm 3.2$ ) and $135(26 \%)$ were female (mean age $10.6 \pm 3.4)$. The mean height value was $144 \mathrm{~cm}$ and the mean weight value was $46 \mathrm{~kg}$. We observed that $95 \%$ of the patients $(n=495)$ were right-hand-dominant. The majority of the traumatic events occurred within the age range of 8-10 (Figure 1).

A total of 1085 teeth were involved, of which 975 were permanent teeth $(89.9 \%)$ and 110 primary teeth $(10.1 \%)$. The most frequently injured permanent teeth were $1.1(n=315)$, $2.1(n=273), 1.2(n=125)$ and $2.2(n=117)$, followed by the lower central incisors (Figure 2). Of the deciduous teeth, the most commonly injured were $5.1(n=46), 6.1(n=31), 5.2$ $(n=12), 6.2(n=9), 7.1(n=5)$ and $8.1(n=7)$ (Figure 3). In terms of involvement, we found no significant difference between the left and the right teeth of the mouth $(p=0.415)$, however, a higher prevalence of maxillary injuries over mandibular ones was observed $(p=0.000)$. The various types of traumatic lesions - divided into dental and periodontal lesions - are shown in Table 1. Mountain bikes (MTB) were used by $91 \%$ of the children $(n=473)$ while the remaining $9 \%(n=47)$ used a racing bicycle. Five hundred and five patients $(97 \%)$ did not wear a helmet. Of the 15 children (3\%) who wore a helmet, 9 were riding a racing bike and 6 a mountain bike. Not one single patient used a mouth-guard. Helmets were worn significantly more by the racing group than by the mountain bike group $\left(\chi^{2}=42, p<0.05\right)$ and, of the mountain bike racers, it was worn more by adventure riders rather than non-adventure riders $\left(\chi^{2}=18.37, p<0.05\right)$. A significant difference was also observed for the type of lesions between the two groups: in the adventure riders group, complex fractures $\left(\chi^{2}=3.2, p<0.05\right)$, traumatic avulsion $\left(\chi^{2}=6.8, p<0.05\right)$, and soft tissue lesions $\left(\chi^{2}=9.2\right.$, $p<0.05$ ) were more common than in the non-adventure riders group.

Out of the 520 children referred to the Dental Clinic for a dental trauma due to a bicycle fall or accident, 57 (11\%) were also treated for bone fractures at the Maxillofacial Department. There were 19 cases (34\%) of mandible fractures, $15(26 \%)$ of the maxillary and the zygomatic bone fractures and $11(19 \%)$ of the orbital bone fractures. Twelve children (21\%) had multiple facial bone fractures. As for soft tissue injuries, 406 cases (78\%) of lacerations and/or contusions

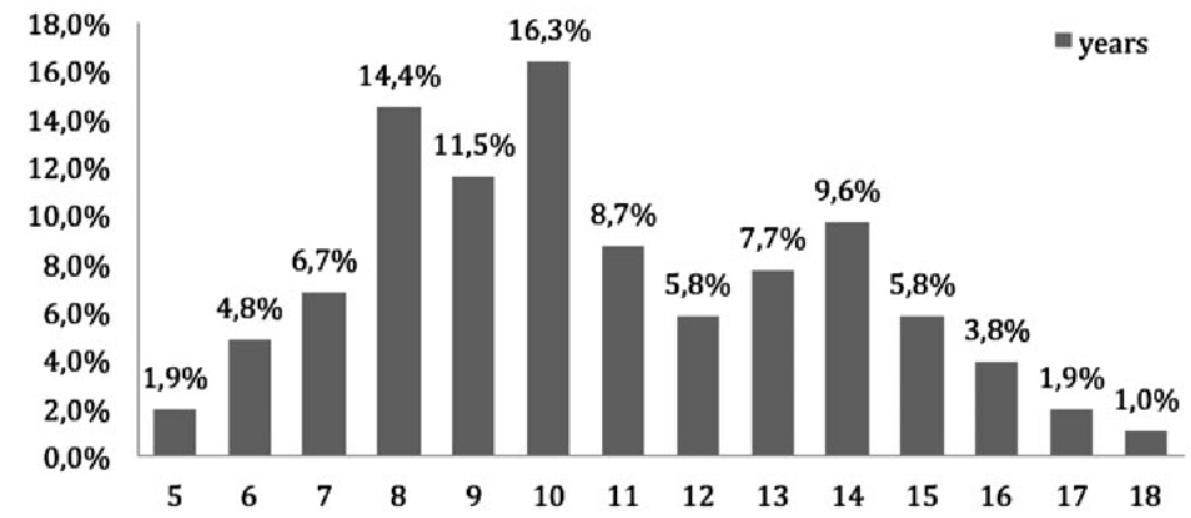

Figure 1. Frequency of oro-facial trauma at different ages. 


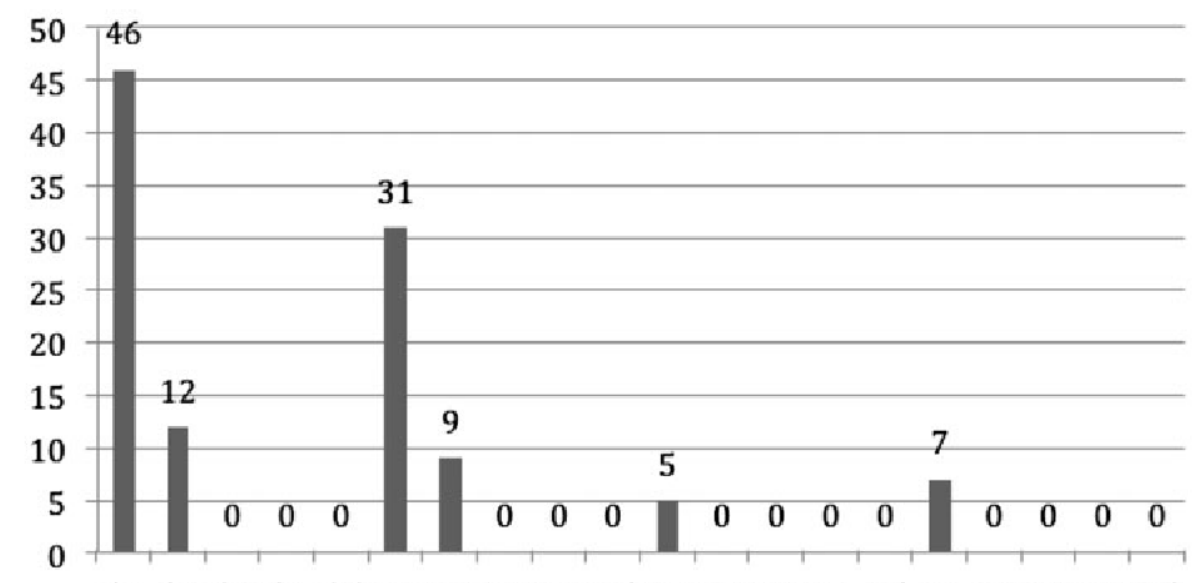

5.15 .25 .35 .45 .56 .16 .26 .36 .46 .57 .17 .27 .37 .47 .58 .18 .28 .38 .48 .5

PRIMARY TEETH

Figure 2. Traumatized primary teeth.

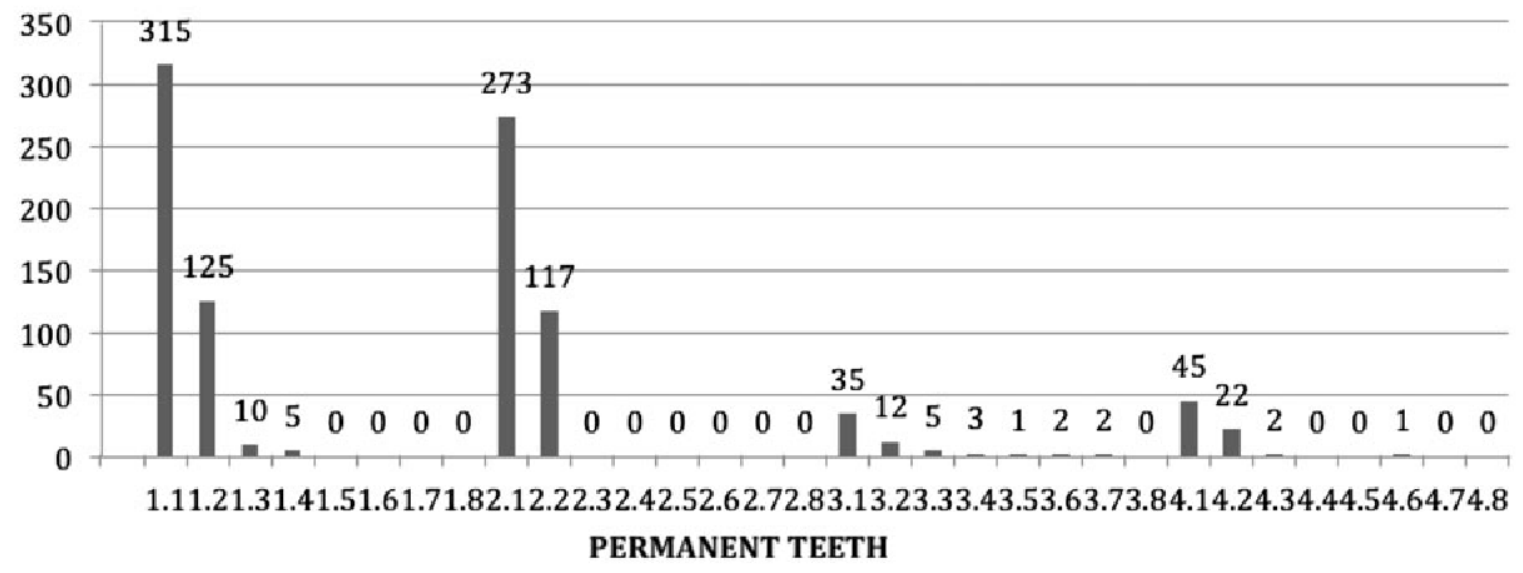

Figure 3. Traumatized permanent teeth.

Table 1. Type of traumatic lesions ( $n$ ).

\begin{tabular}{lc}
\hline Type of dental traumatic lesion & $(n=583)$ \\
\hline Dental injuries & $15(2.5 \%)$ \\
Infraction & $163(28 \%)$ \\
Crown fracture & $17(3 \%)$ \\
Crown fracture with pulp exposure & $17(3 \%)$ \\
Root fracture & $96(16.5 \%)$ \\
$\quad$ Crown-root fracture & \\
Periodontal injuries & $44(7.5 \%)$ \\
Intrusive luxation & $88(15 \%)$ \\
Extrusive luxation & $29(5 \%)$ \\
Lateral luxation & $114(19.5 \%)$ \\
Traumatic avulsion & \\
Bone lesions & $19(34 \%)$ \\
$\quad$ Mandible fractures & $15(26 \%)$ \\
Maxillary and zygomatic fractures & $11(19 \%)$ \\
Orbital fractures & $12(21 \%)$ \\
Multiple fractures & \\
Soft tissue injuries & \\
Lacerations and/or contusions & $406(78 \%)$ \\
\hline
\end{tabular}

were reported. The consistency of damage relative to the side of the face and dominant hand was approximately $96 \%$.

\section{Discussion}

In this study, $37 \%$ of traumas in patients aged 0-18 were due to a bicycle accident. This proportion is within the range reported in literature, which varies from approximately $20 \%$ [15-18] to $35 \%$ and $48 \%[19,20]$. In agreement with the literature [21], our study reported a greater number of injuries in boys compared to girls (approximately 2:1); this can easily be explained by the more frequent involvement of boys in sports and dangerous activities, such as mountain biking. Generally, children younger than 5 experience a low frequency of traumatic accidents due to the protective environment they live in, but for those over the age of 6 , road accidents are the main cause of facial traumas [22]. The cranium is more likely to fracture in an infant due to the cranium-face ratio of 8:1; whereas, with increasing age and development of the paranasal sinus, the face becomes more prone to fractures, with an adult cranium-face ratio of 2:1. Older children and adolescents are more likely to experience face and dental fractures [23], as shown in this study.

Traumatic dental and periodontal must be treated promptly and properly in order to reduce the suffering, costs, and time for patients, parents and health care providers. 
A long-term follow-up, sometimes life-long, for the possible late complications, is often required.

In the present study, the proportion of different types of dental and periodontal lesions corresponded to those reported in literature [24]. Children who, in addition to dental trauma, experienced associated bone facial fractures, were reported to have mostly mandible fractures, followed by the maxillary and zygomatic bone injuries. This is slightly in contrast to other reports $[15,25]$, which found a higher prevalence of middle-face fractures. However, due to the fact that the peak incidence of facial fractures in this study was in older children, the high involvement of mandibular bone fractures could be explained by the larger and more developed mandible, typical of this age range, even if the cheek is generally the first point of collision with the ground [15]. In accordance with literature, our study found the central upper incisors to be the most frequently traumatized teeth, followed by the lateral upper incisors and then by the lower frontal teeth. These data can lead to speculation that there are some predisposing factors in the oral cavity, such as a dental overjet wider than $6 \mathrm{~mm}$, incompetent lips or mouth breathing $[20,26]$. Further studies are needed to investigate these possible correlations.

In 2006, Bourdet et al. [27] reported a graphical representation of head impact points after bicycle accidents (after falls and after impact against the curb); the authors state that there was a high probability of impact to the superior part of the head compared to the inferior and the teeth. These data are in contrast with the high incidence of bicyclerelated dental trauma reported in other literature [28] and also with the data collected in this study. As bicycle-related injuries are multi-factorial, how the accident happened should be considered. If the anterior wheel of the bicycle is suddenly blocked due to an obstacle, the contact point between wheel and terrain acts as a pivot, and the cyclist and the bike are catapulted forward. Usually, due to the speed, the cyclist cannot remove his/her hands from the handlebars in order to protect his/her face, and the impact with the ground causes injuries to the face, mouth and teeth [29]. It is interesting to note how, in our study's sample, the children had injuries usually only on one side of the face, in particular, right handed cyclists presented injuries on the right side of the face and likewise left handed cyclists on the left side. Although just $5 \%$ of the sample were left-handed and the difference was not significant, the location of injury could still be explained by the impact dynamics as explained above.

There are multiple reasons for accidental falls, such as distraction, poor road conditions, dangerous stunts and collision with other vehicles/pedestrians or loss of balance. When a collision happens, cyclists are at a disadvantage because of the lack of safety equipment such as helmets and mouth guards. No patients included in this study wore an athletic mouth guard (AMG); a fact that is almost embarrassing. Although the role of AMG in reducing the incidence and severity of dental trauma is well known and it is regulated in various different professional contact sports [28], its use is still rare among cyclists, as confirmed by our stud. AMGs absorb the force from a frontal and axial impact, dissipating it over a wide area
[30]. In a recent survey conducted in Italy among children and adolescents who practiced sports, $80 \%$ admitted to know about the protective benefits of AMG as a protective device. Nevertheless only $5 \%$ of athletes had actually worn one during practice. The reasons for which they did not wear AMGs were discomfort and difficulty in breathing. [31]. Moreover, none of the children/adolescents received information about these protective devices from their teachers. The same results are shown in another survey conducted by Muller et al. [28], where none of the Italian mountain bikers wore AMGs. The lack of information from parents (and also from coaches and teachers) could partially explain the shocking results about AMGs in this study, seeing as the use of protective devices should be enforced in all sports. From this point of view, the dentist could have a key role in promoting the use of AMGs in cyclists, particularly in children, through pictures, illustrated billboards or interactive games.

All the data recorded in this study and in literature stress about the excessively low number of helmet-users. Under the age of 15 the use of helmets is mandatory by law only in some Eastern and Western European countries, while in the rest of Europe, its use is just recommended. Although the importance of a helmet is well documented for the prevention and reduction of TBI as well as for facial injuries $[3,32]$, a helmet's design does not protect the lower third of the face and the teeth $[1,15,33]$. In order to protect these areas, a helmet would need to be a full-face one with faceguard [34].

In this study, the use of helmets seems to be more frequent in children and adolescents who use racing-bikes competitively compared to mountain bikers. This could be explained by the fact that racing cyclists often ride at high speeds on the road with cars and other means of transport. Therefore they perceive a greater sense of danger. Instead, mountain bikers, mainly non-adventure ones, often ride for fun, without taking into consideration the dangerous possibility of falling.

This study leads to the conclusion that wearing a bicycle helmet and a mouth guard should be strongly recommended for children and adolescents. National and regional efforts should be made to promote head and mouth protection in cycling. Projects regarding the promotion of bicycle safety should actively include paediatricians and dentists, to encourage the wider acceptance and use of safety precautions.

\section{Disclosure statement}

The authors report no conflicts of interest. The authors alone are responsible for the content and writing of this article.

\section{Notes on contributors}

Francesca Amadori, is a Research Fellow of Paediatric Dentistry.

Elena Bardellini, is a Researcher of Paediatric Dentistry.

Alessandro Copeta, is a Researcher of Mechanical Engineering.

Giulio Conti, is a Research Fellow of Oral Surgery.

Valerio Villa, is an Associate Professor of Mechanical Engineering.

Alessandra Majorana, is a Full Professor of Paediatric Dentistry. 


\section{References}

[1] Junior SM, Santos SE, Kluppel LE, et al. A comparison of motorcycle and bicycle accidents in oral and maxillofacial trauma. J Oral Maxillofac Surg. 2012;70:577-583.

[2] Haug R, Foss J. Maxillofacial injuries in the pediatric patient. Oral Surg Oral Med Oral Pathol Oral Radiol Endod. 2000;90:126-134.

[3] Chapman HR, Curran A. Bicycle helmets-does the dental profession have a role in promoting their use? Br Dent J. 2004;196: 555-560.

[4] Fakhruddin KS, Lawrence HP, Kenny DJ, et al. Impact of treated and untreated dental injuries on the quality of life of Ontario school children. Dent Traumatol. 2008;24:309-313.

[5] Glendor U, Marcenes W, Andreasen JO. Classification, epidemiology and etiology. In: Andreasen JO, Andreasen FM, Andersson L, editors. Textbook and color atlas of traumatic injuries to the teeth. 4th ed. Chapter 8. Oxford: Blackwell Munksgaard; 2007. p. 228.

[6] Thompson DC, Rivara FP, Thompson R. Helmets for preventing head and facial injuries in bicyclists (Cochrane review). The Cochrane library, Issue 1. Oxford: Update Software; 2003.

[7] Orsi C, Ferraro OE, Montomoli C, et al. Alcohol consumption, helmet use and head trauma in cycling collisions in Germany. Accid Anal Prev. 2014;65:97-104.

[8] Ritter N, Vance C. The determinants of bicycle helmet use: evidence from Germany. Accid Anal Prev. 2011;43:95-100.

[9] Glendor U. Aetiology and risk factors related to traumatic dental injuries-a review of the literature. Dent Traumatol. 2009;25:19-31.

[10] Eilert-Petersson E, Andersson L, Sörensen S. Traumatic oral vs non-oral injuries. Swed Dent J. 1997;21:55-68.

[11] Laflamme L, Eilert-Petersson E. Injuries to pre-school children in a home setting: patterns and related products. Acta Paediatr. 1998;87:206-211.

[12] Burlini D, Conti G, Amadori F, et al. Management of paediatric maxillofacial fractures: conventional methods and resorbable materials. Eur J Paediatr Dent. 2015;16:24-28.

[13] Powell EC, Tanz RR. Cycling injuries treated in emergency departments: need for bicycle helmets among preschoolers. Arch Pediatr Adolesc Med. 2000;154:1096-1100.

[14] Andreasen JO. Texbook and color atlas of traumatic injuries to the teeth. Copenhagen: Munksgaard; 1994.

[15] Lee KH, Chou HJ. Facial fractures in road cyclists. Aust Dent J. 2008;53:246-249.

[16] Eggensperger N, Holzle A, Zachartiou Z, et al. Pediatric craniofacial trauma. J Oral Maxillofac Surg. 2008;66:58-64.
[17] Scariot R, de Oliveira IA, Passeri LA, et al. Maxillofacial injuries in a group of Brazilian subjects under 18 years of age. J Appl Oral Sci. 2009;17:195-198.

[18] Gassner R, Tuli T, Hachl O, et al. Craniomaxillofacial trauma in children: a review of 3385 cases with 6060 injuries in 10 years. J Oral Maxillofacial Surg. 2004;62:339-407.

[19] Munante-Cardenas JL, Olate S, Asprino L, et al. Pattern and treatment of facial trauma in pediatric and adolescent patients. J Craniofac Surg. 2011;22:1251-1255.

[20] Gassner R, Hackl W, Tuli T, et al. Differential profile of facial injuries among mountainbikers compared with bicyclists. J Trauma. 1999;47:50-54.

[21] Cole $P$, Kaufman $Y$, Hollier LH. Managing the pediatric facial fractures. Craniomaxillofac Trauma Reconstr. 2009;2:77-84.

[22] Kaban LB. Diagnosis and treatment of fractures of the facial bones in children 1943-1993. J Oral Maxillofac Surg. 1993;51:722-729.

[23] Shaikh ZS, Worral SF. Epidemiology of facial trauma in a sample of patients aged 1-18 years. Injury. 2002;33:669-671.

[24] Lieger O, Zix J, Kruse A, et al. Dental injuries in association with facial fractures. J Oral Maxillofac Surg. 2009;67:1680-1684.

[25] Lindqvist C, Sorsa S, Hyrkas T, et al. Maxillofacial fractures sustained in bicycle accidents. Int J Oral Maxillofac Surg. 1986;15:12-18.

[26] ElKarmi RF, Hamdan MA, Rajab LD, et al. Prevalence of traumatic dental injuries and associated factors among preschool children in Amman, Jordan. Dent Traumatol. 2015;31:487-492.

[27] Bourdet N, Deck C, Serre T, et al. In-depth real-world bicycle accident reconstructions. Int J Crashworthines. 2014;19:222-232.

[28] Muller KE, Persic R, Pohl Y, et al. Dental injuries in mountain biking-a survey in Switzerland, Austria, Germany and Italy. Dent Traumatol. 2008;24:522-527.

[29] Syed H, Willing R, Jenkyn TR, et al. Video analysis of the biomechanics of a bicycle accident resulting in significant facial fractures. J Craniofac Surg. 2013;24:2023-2029.

[30] Patrick DG, van Noort R, Found MS. Scale of protection and the various types of sports mouthguards. $\mathrm{Br} J$ Sports Med. 2005;39:278-281.

[31] Biagi R, Cardarelli F, Butti AC, et al. Sports-related dental injuries: knowledge of first aid and mouthguard use in a sample of Italian children and youngsters. Eur J Paediatr Dent. 2010;11:66-70.

[32] McDermott F. Bicyclist head injury prevention by helmets and mandatory wearing legislation in Victoria, Australia. Ann R Coll Surg Engl. 1995;77:38-44.

[33] Amoros E, Chiron M, Martin JL, et al. Bicycle helmet wearing and the risk of head, face, and neck injury: a French case-control study based on a road trauma registry. Inj Prev. 2012;18:27-32.

[34] Acton CH, Nixon JW, Clark RC. Bicycle riding and oral/maxillofacial trauma in young children. Med J Aust. 1996;165:249-251. 